\title{
Inhibition of the DNA-Dependent Protein Kinase for Cancer Therapy
}

\section{Suzannah J Harnor, Alfie Brennan and Céline Cano*}

Northern Institute for Cancer Research, School of Chemistry, Newcastle University, Newcastle upon Tyne, NE1 7RU, UK

\section{Abstract}

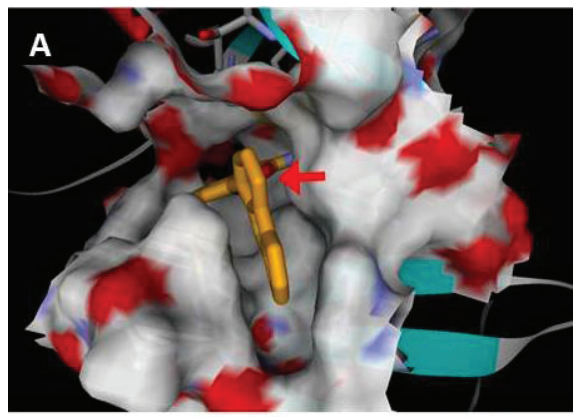

The catalytic activity of DNA-dependent protein kinase (DNA-PK) is central to its ability to repair lethal DNAdouble strand breaks (DSBs). This includes repair of DSB lesions following therapeutic treatment of cancer cells or resulting from oxidative stress or oncogene-induced transcription. As a tactic to induce tumour chemo- and radio-sensitisation, numerous attempts have been made to identify small molecule inhibitors of DNA-PK activity. This review examines the structures of known reversible and irreversible inhibitors, including those based upon chromen-4-one, arylmorpholine, and benzaldehyde scaffolds. VX-984 and M3814 are recent examples of DNA-PK catalytic inhibitors that have progressed into clinical development, the results from which should help to further advance our understanding of whether this approach represents a promising therapeutic strategy for the treatment of cancer.

Keywords: Chemopotentiation; DNA damage response; DNA-PK; Inhibitor; Kinase; NHEJ

\section{Introduction}

DNA double-strand breaks (DSBs) are a highly toxic form of DNA damage that can be caused by reactive oxygen species (ROS) naturally occurring in eukaryotic cells as well as exogenous stimuli, such as ionising radiation. A key protein involved in the repair of these lesions is DNA-dependent protein kinase (DNA-PK). The active DNA-PK complex is composed of a catalytic serine/threonine protein kinase (DNA-PKcs) and two heterodimeric subunits (Ku70 and Ku80) which bind to the DSB and direct the catalytic subunit to the site requiring repair $[1,2]$. Even a single DSB has the potential to cause a genomic rearrangement resulting in a mutation that could have fatal consequences for the cell. The evolutionary response to this lethality has been the development of three independent pathways capable of repairing DNA DSBs. Homologous recombination (HR) takes place during the $S$ and G2 phases of the cell cycle when sister chromatids are available to act as a template, thereby allowing highly accurate repair of the genome [3]. Non-homologous end joining (NHEJ) can occur throughout the cell cycle, although it is critically important during the G1 phase before DNA replication, allowing cells to constantly maintain genomic integrity [4-6]. The third pathway, microhomology-mediated end joining (MMEJ), is a mutagenic process that only occurs when a cell is unable to effectively utilise HR and NHEJ. The kinase activity of DNA-PK has been shown to be critically important for effective NHEJ to take place. Once the Ku heterodimer has bound to the site of a DSB, recruitment of the DNA-PKcs takes place leading to a shift in the conformation of the heterodimer which simultaneously tethers the broken ends of the strands together and stimulates kinase activity $[7,8]$. DNA-PKcs has been shown to have altered activity and expression in several tumour types. Studies in chronic lymphocytic leukaemia (CLL) have demonstrated that increased DNA-PKcs activity correlated with resistance to DNA damage inducing chemotherapeutics and reduced treatment free interval $[9,10]$. Elevated DNA-PKcs expression has also been reported in gastric cancer [11] and found to correlate with poor patient prognosis in ovarian cancer [12] and hepatocellular carcinoma (HCC) [13]. The evidence identifying DNA-PK as a key marker for treatment resistant tumours has driven many attempts to find suitable inhibitors of DNA-PKcs kinase activity. DNA-PK is a large (555 kDa), multi-component enzyme and as such has proved a highly challenging target for structural biology - often a crucial facet of modern drug discovery campaigns. As such, campaigns to identify potent inhibitors have relied upon more traditional screening and optimisation processes. Inhibitors so far identified have varied widely with respect to potency, selectivity, and reversibility - although all have been type 1 inhibitors competing directly with the ATP binding site of the catalytic domain. DNA-PKcs is a member of the phosphatidylinositol 3-kinase related kinase (PIKK) family, which includes proteins such as ATM (Ataxia telangiectasia mutated kinase), ATR (AT and Rad3-related kinase), and mTOR (Mammalian Target of Rapamycin) all of which have been the targets of anti-cancer drug discovery efforts - including

*Corresponding author: Céline Cano, Northern Institute for Cancer Research, School of Chemistry, Newcastle University, Bedson Building, Newcastle upon Tyne, NE1 7RU, UK, Tel: 4401912087060; E-mail: celine.cano@ncl.ac.uk

Received May 22, 2017; Accepted May 27, 2017; Published June 03, 2017

Citation: Harnor SJ, Brennan A, Cano C (2017) Inhibition of the DNA-Dependent Protein Kinase for Cancer Therapy. Med Chem (Los Angeles) 7: 172-177. doi: 10.4172/2161-0444.1000452

Copyright: ( $) 2017$ Harnor SJ, et al. This is an open-access article distributed under the terms of the Creative Commons Attribution License, which permits unrestricted use, distribution, and reproduction in any medium, provided the original author and source are credited. 
the development of several clinical candidates [4-6]. Good selectivity over these enzymes is therefore essential before a tool compound can be used to accurately assess the in vivo relevance of DNA-PK inhibition.

\section{DNA-PK Small Molecule Inhibitors}

\section{Wortmannin}

Wortmannin (1) is a natural fungal metabolite, derived from Penicillium wortmannii $K$ and first observed to have antifungal and anti-inflammatory properties. This steroidal derivative is a potent and selective inhibitor of PI3K family kinases without activity against other intracellular signalling enzyme targets, inhibiting PI3K activity with an $\mathrm{IC}_{50}$ of $4.2 \mathrm{nM}[14]$ (Scheme 1).

Kinetic analysis of the PI3K inhibition by wortmannin indicated a non-competitive irreversible inhibition, further verified with cocrystallographic studies of the resulting covalent complex in the ATPbinding pocket of $\mathrm{PI} 3 \mathrm{~K} \gamma[15,16]$. Subsequent work demonstrated that wortmannin also inhibits DNA-PK $\left(\mathrm{IC}_{50}=16 \mathrm{nM}\right)$ by a noncompetitive mechanism, forming covalent adducts with DNA-PKcs lysine 802 in the region of the molecule harbouring its kinase domain [17]. Although the activity of this sterol-like structure and its mode of interaction made it an interesting early tool compound, the relative structural complexity of wortmannin, together with its irreversible inhibition and poor selectively, limit its potential as a drug molecule. Despite these limitations, wortmannin was used to demonstrate a 3-5fold enhancement of IR-induced cytotoxicity and an inhibition of IRinduced DSB repair in Chinese hamster ovary cells [18].

\section{Chromen-4-ones and surrogates: LY2094002 and derivatives}

In the early 1990's, Lilly pharmaceuticals undertook a screen of compounds derived from quercetin (2), with the objective of developing PI3K-specific inhibitors. The chromen-4-one structure LY294002 (3) was reported as an inhibitor of PI3K [19] (Scheme 2).

Subsequent evaluation of $\mathbf{3}$ as a DNA-PK inhibitor, showed that the compound exhibited similar DNA-PK inhibitory activity to that against PI3K, highlighting the non-selective profile of the compound (Table 1) $[19,20]$.

The importance of the oxygen of the morpholine substituent of 3 was verified, and while replacement by thiomorpholine (4) dramatically reduced potency, the piperidine derivative $\mathbf{5}$ proved essentially devoid of DNA-PK inhibitory activity. The key role of the morpholine substituent of $\mathbf{3}$ was later substantiated by X-ray crystallography, when the structure of $\mathbf{3}$ in complex with human PI $3 \mathrm{~K} \gamma$ revealed that the morpholine oxygen makes a hydrogen bond interaction with the backbone amide group of Val-882 within the ATP-binding domain of the kinase (Figure 1) [16].

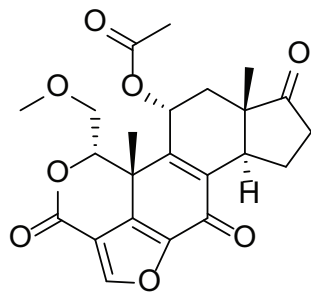

1: Wortmannin

Scheme 1: Wortmannin.<smiles>O=c1cc(-c2ccc(O)c(O)c2)oc2cc(O)cc(O)c12</smiles><smiles>[X][M]C1CCN(c2cc(=O)c3cccc(-c4ccccc4)c3o2)CC1</smiles>

3: LY294002; X = O

4: $X=S$

5: $\mathrm{X}=\mathrm{CH}_{2}$

Scheme 2: Chromen-4-ones and Surrogates: LY2094002 and Derivatives.

\begin{tabular}{|l|c|c|c|c|c|}
\hline PIKK & DNA-PK & PI3K $\left(\mathbf{p} 110_{\alpha}\right)$ & ATM & ATR & mTOR \\
\hline IC $_{50}(\mu \mathrm{M})$ & $1.5 \pm 0.2^{\mathrm{a}}$ & $2.3 \pm 0.8^{\mathrm{a}}(1.4)^{\mathrm{b}}$ & $>100^{\mathrm{a}}$ & $>100^{\mathrm{a}}$ & $2.5 \pm 0.2^{\mathrm{a}}$ \\
\hline
\end{tabular}

aValues from Ref [19]; ' Literature value from Ref [20]

Table 1: Reported inhibitory activity of LY294002 (3) against different PIKK family members.

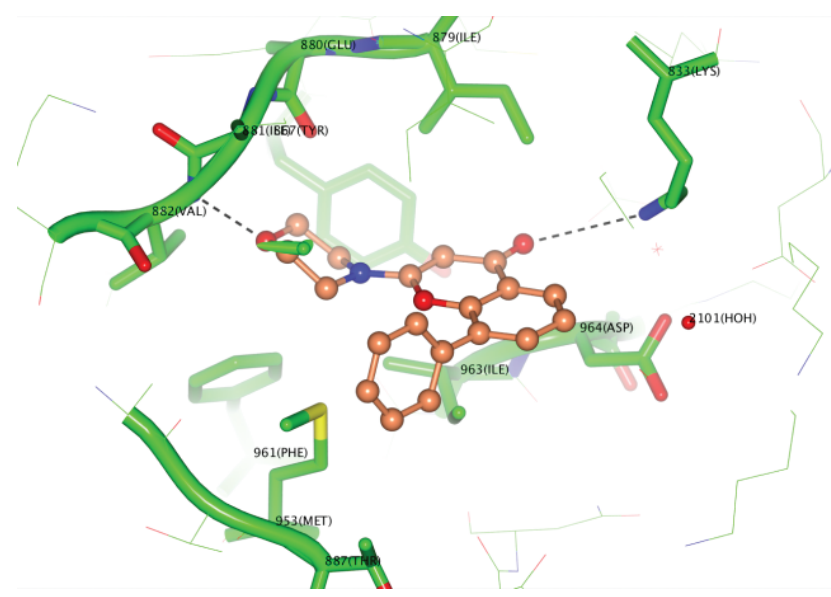

Figure 1: Crystal structure of LY294002 (3) in complex with the ATP-binding domain of PI3Ky.

Despite suffering from high clearance (1h) and in vivo toxicity, 3 aided in the development of derivatives with improved potency and selectivity against DNA-PK, and superior physicochemical properties. Research conducted at the Northern Institute for Cancer Research at Newcastle University in collaboration with KuDOS Pharmaceuticals investigated a series of benzopyranones and pyrimidoisoquinolinones [20]. Incorporation of a fused ring on the chromenone, gave a 5-fold improvement in potency against DNA-PK (NU7026 (6); DNA-PK $\left.\mathrm{IC}_{50}=0.23 \mu \mathrm{M}\right)$ (Table 2) and introduction of a methyl group on the morpholine ring was equipotent $\left(7 ; \mathrm{DNA}-\mathrm{PK} \mathrm{IC}_{50}=0.19 \mu \mathrm{M}\right)$. Additional methyl groups, at the 2 or 6-position of morpholine, or replacement of the morpholine ring altogether (e.g., piperidine, piperazine) resulted in a loss of activity [20,21]. These early derivatives showed better selectivity for DNA-PK over other PIKK family members than the parent compound, e.g., 6 is 60 -fold more potent against DNA-PK than PI3K (p110 $\alpha)$ (Table 2 and Scheme 3).

Replacement of the chromen-4-one scaffold by the isosteric pyrimidoisoquinolinone structure gave equipotent compounds (8; $\left.\mathrm{IC}_{50}=0.28 \mu \mathrm{M}\right)[22]$. Multiple studies have revealed that 6 acts in vitro as a radiosensitiser, [23] and as a chemo-potentiator of topoisomerase II (TOP2) poisons in human leukaemia cell lines [24]. 


\begin{tabular}{|c|c|c|c|c|c|}
\hline & DNA-PK & PI3K $(\mathbf{p 1 1 0} \alpha)$ & ATM & ATR & mTOR \\
\hline $\mathbf{6}$ & 0.23 & 13 & $>100$ & $>100$ & 6.2 \\
\hline $\mathbf{7}$ & 0.19 & 2.4 & $>100$ & $>100$ & 4.8 \\
\hline $\mathbf{8}$ & 0.28 & $>100$ & $>100$ & $>100$ & 5.3 \\
\hline
\end{tabular}

Table 2: Inhibitory activity $\left(\mathrm{IC}_{50} \mu \mathrm{M}\right)$ against different PIKK family members [20]

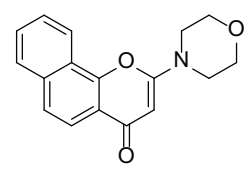

6: NU7026

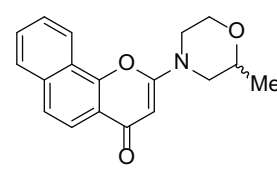

7

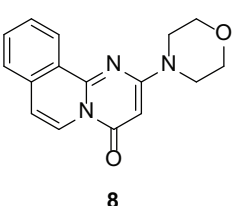

8
Scheme 3: potency against DNA-PK (NU7026 (6); DNA-PK IC $\left.{ }_{50}=0.23 \mu \mathrm{M}\right)$.

In a bid to simplify the chromenone core, synthesis of a series of substituted monocyclic pyran-2-one, pyran-4-one, thiopyran-4-one and pyridin-4-one derivatives was carried out [25]. The pyran-4-one system and substitution at the pyranone 3- or 5-positions gave a loss of activity. However, library work on 6-substituted-2-morpholinopyran-4-one and 6-substituted-2-morpholinothiopyran-4-one, led to the identification of 9 (DNA-PK; $\mathrm{IC}_{50}=0.18 \mu \mathrm{M}$ ) and 10 (DNA-PK $\left.\mathrm{IC}_{50}=0.19 \mu \mathrm{M}\right)$, both 10 -fold more potent against DNA-PK than the parent $3[25,26]$ (Scheme 4).

Significant improvement in potency and selectivity against DNA-PK was attained as a result of a multi-parallel library approach to synthesise 6-, 7- and 8-aryl substituted chromen-4-ones [27]. Interestingly, compound 11 (DNA-PK $\mathrm{IC}_{50}=0.11 \mu \mathrm{M}$ ) showed a 10 fold increase in potency compared to 3 , whereas the dibenzofuranyl derivative (12) (DNA-PK IC $\left._{50}=0.04 \mu \mathrm{M}\right)$ was the first sub-micromolar inhibitor of DNA-PK. The incorporation of a dibenzothiophenyl group led to NU7441 (13), a compound with a 100-fold increase in potency compared with the parent phenyl derivative 3 (DNA-PK IC I $_{50}=0.02 \mu \mathrm{M}$ ), along with excellent selectivity over other PIKK family members (Table 3 ).

Characterisation using the SW620 and LoVo cell lines found that $1 \mu \mathrm{M} 13$ enhanced the cytotoxicity of TOP2 inhibitors etoposide (2- to 12 -fold) and doxorubicin (2- to 10 -fold) as well as ionising radiation (IR) (2- to 4-fold) [28]. Importantly, in vivo studies showed that even with relatively poor solubility, $\mathbf{1 3}$ increased etoposide-induced tumour growth delay in the SW620 tumour xenograft model [28].

An homology model of the ATP-binding site of DNA-PK, derived from the crystal structure of PI $3 \mathrm{~K} \gamma$ was used to guide further inhibitor design [29]. The model predicted that groups substituted at the dibenzothiophene 1-position of $\mathbf{1 3}$, would be directed out of the binding pocket into bulk solvent (Figure 2A, red arrow).

The newly synthesised compounds all possessed polar substituents at the dibenzothiophene 1-position, with an aim to improve potency and physicochemical properties [30]. A number of the compounds exhibited high potency against DNA-PK and potentiated the cytotoxicity of IR in vitro 10 -fold or more (e.g., 14; DNA-PK IC I0 $_{50}=5.0 \pm 1 \mathrm{nM}$, IR dose modification ratio=13). Furthermore, 14 was shown to potentiate not only IR in vitro but also DNA-inducing cytotoxic anticancer agents, both in vitro and in vivo. A counter-screen against other members of the PI3K PIKK family revealed that some of the compounds were potent mixed DNA-PK and PI3K inhibitors, including 14 [30,31]. The favourable biological activity of $\mathbf{1 4}$ was complemented by superior drug-like properties compared to NU7441 (13), and acceptable plasma

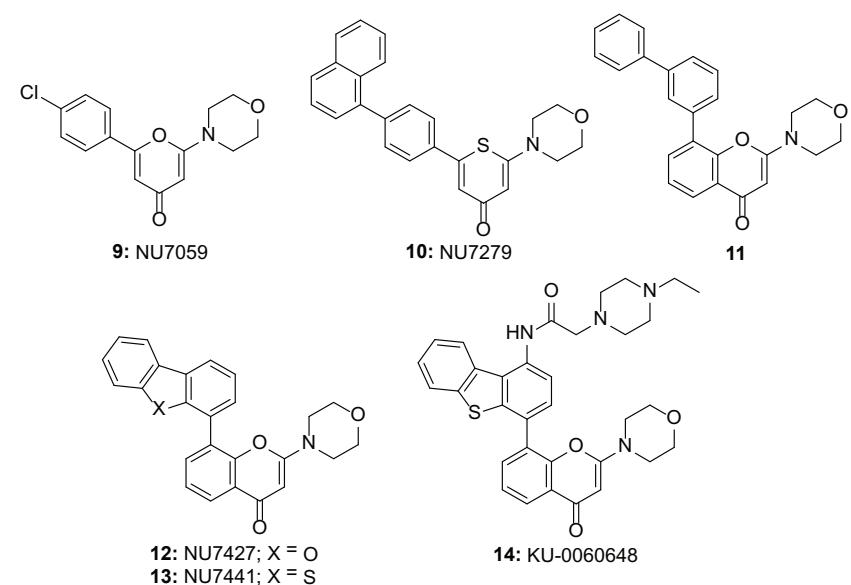

Scheme 4: Incorporation of a dibenzothiophenyl group led to NU7441 (13).
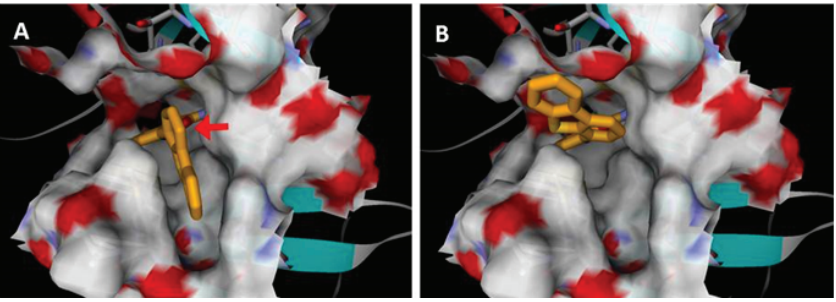

Figure 2: Homology model of the ATP-binding site of the DNA-Dependent Protein Kinase (DNA-PK) used to guide inhibitor design [29]. The 3D mode was constructed on the basis of the known X-ray crystal structure of PI3K from RCSB protein data bank (PDB ID: 1E7V) as a template, and with Prime in Maestro molecular modelling program (licensed from Schrödinger, LGG). NU7441 (13) is represented in (A) an orthogonal, and (B) 'in plane' pose.

protein binding, combined with weak activity against hERG and a panel of cytochrome P450 (CYP) drug-metabolising enzymes (Table 4) [30].

[a] Amorphous material (crystalline solubility at $\mathrm{pH} 7.4$ buffer $=6.0 \mu \mathrm{M}$ )

[b] Tested in CYP 3A4, 2D6, 2C9, 2C19 and 1A2

In efforts to optimise the biological and pharmaceutical properties of $\mathbf{1 3}$, and to expand structure-activity relationships (SARs), the core chromenone scaffold as well as the dibenzothiophen-4-yl moiety have been systematically modified [32,33]. As 11 is approximately 10 -fold more potent than the parent 8-phenylchromenone (3) this strongly indicated that the 3-phenyl substituent of $\mathbf{1 1}$ made additional binding interactions within the ATP-binding domain of DNA-PK. By probing this presumed binding interaction further, replacement of the 3-phenyl group of 11 by an isosteric thiophen-2-yl substituent (15) improved DNA-PK inhibitory activity approximately 10 -fold (DNA PK; $\mathrm{IC}_{50}=18$ $\mathrm{nM}$ ) [32]. Homology modelling studies indicated that the heteroaryl substituent may occupy a putative hydrophobic pocket, with further SAR resulting in the discovery of $O$-alkoxyphenylchromen-4-one (16) (DNA PK; $\mathrm{IC}_{50}=8 \mathrm{nM}$ ) $[32,33]$.

Resolvable atropisomeric derivatives of $\mathbf{3}$ have also been described. Introduction of a methyl substituent, as a representative example, at the dibenzothiophene 3-position (17) (DNA PK; $\mathrm{IC}_{50}=1.7 \mu \mathrm{M}$ ) or at the chromenone 7-position (18) (DNA PK; $\left.\mathrm{IC}_{50}=0.005 \mu \mathrm{M}\right)$ of 13, generated stable pairs of atropisomers due to restricted rotation between the chromen-4-one and dibenzothiophene rings [29,34]. Substitution 
Citation: Harnor SJ, Brennan A, Cano C (2017) Inhibition of the DNA-Dependent Protein Kinase for Cancer Therapy. Med Chem (Los Angeles) 7: 172-177. doi: 10.4172/2161-0444.1000452

\begin{tabular}{|l|c|c|c|c|c|c|}
\hline & DNA-PK & PI3K & PI4K $\boldsymbol{\beta}$ & ATM & ATR & mTOR \\
\hline IC $_{50}(\boldsymbol{\mu M})$ & 0.012 & 5 & 40 & $>100$ & $>100$ & 1.7 \\
\hline
\end{tabular}

Table 3: NU7441 (13) inhibitory activity against different kinases of the PIKK family.

\begin{tabular}{|c|c|c|c|}
\hline Assay & Data & 13 & 14 \\
\hline Enzyme & DNA-PK IC $_{50}(\mathrm{nM})$ & $42 \pm 2$ & $5.0 \pm 1$ \\
\hline \multirow{3}{*}{$\begin{array}{l}\text { Cellular } \\
\text { (HeLa) }\end{array}$} & pDNA-PK EC ${ }_{50}(\mathrm{nM})$ & 212,339 & $136 \pm 17$ \\
\hline & DMR (0.1 $\mu$ M DNA-PK inhibitor) & $2.2 \pm 0.2$ & $4.0 \pm 0.4$ \\
\hline & DMR (0.5 $\mu \mathrm{M}$ DNA-PK inhibitor) & $2.8 \pm 0.1$ & $13 \pm 2$ \\
\hline \multirow[t]{3}{*}{ Other } & $\begin{array}{l}\log D(\mathrm{pH}=7.4) \\
\operatorname{hERG~IC}_{50}(\mu \mathrm{M})\end{array}$ & $\begin{array}{c}>4.3 \\
14,19\end{array}$ & $\begin{array}{l}3.05 \\
>20\end{array}$ \\
\hline & Solubility at $\mathrm{pH} 7.4(\mu \mathrm{M})$ & $<0.3,<0.2$ & $161 \pm 103^{a}$ \\
\hline & $\begin{array}{l}\text { Human plasma protein binding (\% Free) } \\
\mathrm{CYP}_{450} \text { inhibition }(\mu \mathrm{M})^{\mathrm{b}}\end{array}$ & $\begin{array}{c}0.04,0.17 \\
-\end{array}$ & $\begin{array}{c}6.2,3.6 \\
>10\end{array}$ \\
\hline
\end{tabular}

DMR, the dose modification ratio, defined as the percentage of cell survival in the absence of compound with 2 Gy treatment divided by that in the presence of compound plus 2Gy treatment as determined in 6-8 day clonogenic assays; logD, the distribution coefficient calculated as the ratio for the sum of all species of a compound in 1-octanol versus that in water at equilibrium; hERG, the human ethera-go-go-related gene.

Table 4: Properties of NU7441 (13) and KU-0060648 (14) (Data are the mean \pm the standard deviation or individual values; adapted from Ref [30]).

at the dibenzothiophene 3-position (17) resulted in an approximately 60 -fold reduction in potency of the racemic compound against DNAPK compared with the parent compound (13). Interestingly, 18 showed a 6-fold improvement in potency compared with the parent compound (Table 5).

After resolution by chiral high-performance liquid chromatography (HPLC), biological evaluation against DNA-PK of each pair of atropisomers showed that DNA-PK inhibitory activity resided exclusively in the (-)-atropisomer enantiomer, with the antipodal (+)-atropisomer proving inactive at $100 \mu \mathrm{M}[29,35]$ (Scheme 5).

\section{Phenol related IC series}

Reported by the ICOS Corporation and Array Biopharma as part of a new series of DNA-PK inhibitors, 2-hydroxy-4-morpholin-4yl-benzaldehyde (IC60211, $\mathrm{IC}_{50}=400 \mathrm{nM}$ ) (19) is a representative example of DNA-PK inhibitors possessing a morpholine motif [36]. Optimisation of $\mathbf{1 9}$ led to the identification of a number of selective inhibitors (all maintaining the critical arylmorpholine substructure), including IC87361 (20), found to be 50-fold more selective for DNAPK than for p110 $\beta[36,37]$ (Table 6 and Scheme 6).

It has been demonstrated in animal models, that compounds in this series are relatively nontoxic and have improved pharmacokinetic profiles over other specific DNA-PK inhibitors, while enhancing the efficacy of IR in vitro and in vivo [37,38].

\section{SU11752}

In their efforts towards developing a specific DNA-PK inhibitor, Sugen researchers employed a screening campaign of 3-substituted indolin-2-ones and successfully identified the ATP-competitive DNAPK inhibitor SU11752 (21). Compound 21 showed good potency against DNA-PK $\left(\mathrm{IC}_{50}=0.13 \pm 0.028 \mu \mathrm{M}\right)$ and selectivity for DNA-PK over PI3K (p110 $\left.\gamma ; \mathrm{IC}_{50}=1.10 \mu \mathrm{M}\right)$ [39] (Scheme 7).

\section{VX-984}

VX-984 (22), disclosed by Vertex Pharmaceuticals, is a DNA-PK inhibitor currently undergoing a phase I clinical study, in combination with pegylated liposomal doxorubicin in patients with advanced solid

\begin{tabular}{|c|c|c|c|}
\hline & $\mathbf{R}^{\mathbf{1}}$ & $\mathbf{R}^{\mathbf{2}}$ & DNA-PK inhibition \\
\hline $\mathbf{1 3}$ & $\mathrm{H}$ & $\mathrm{H}$ & 0.03 \\
\hline $\mathbf{1 7}$ & $\mathrm{Me}$ & $\mathrm{H}$ & 1.7 \\
\hline $\mathbf{1 7 - ( - )}$ & $\mathrm{Me}$ & $\mathrm{H}$ & 1.2 \\
\hline $\mathbf{1 7 - ( + )}$ & $\mathrm{Me}$ & $\mathrm{H}$ & 100 \\
\hline $\mathbf{1 8}$ & $\mathrm{H}$ & $\mathrm{Me}$ & 0.005 \\
\hline $\mathbf{1 8 - ( - )}$ & $\mathrm{H}$ & $\mathrm{Me}$ & 0.002 \\
\hline $\mathbf{1 8 - ( + )}$ & $\mathrm{H}$ & $\mathrm{Me}$ & 7 \\
\hline
\end{tabular}

Table 5: Inhibition of DNA-PK $\left(\mathrm{IC}_{50} \mu \mathrm{M}\right)$ by 3-substituted dibenzothiophen-4-yl derivatives and 7-substituted chromen-4-one derivatives.

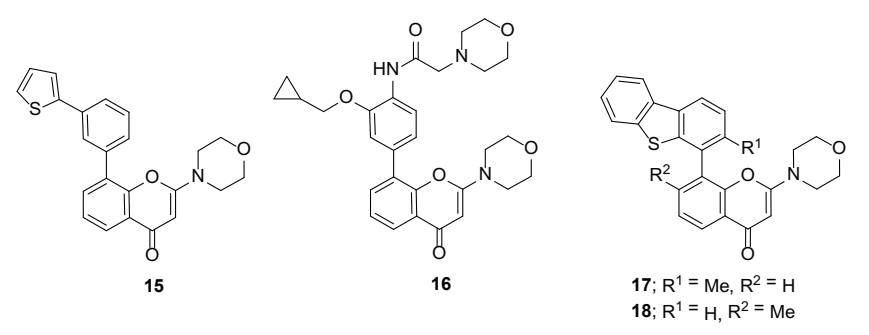

Scheme 5: Antipodal (+)-atropisomer proving inactive at $100 \mu \mathrm{M}$.

\begin{tabular}{|c|c|c|c|c|c|}
\hline & DNA-PK & $\mathbf{p 1 1 0}$ & $\mathbf{p 1 1 0}_{\boldsymbol{\alpha}}$ & $\mathbf{p 1 1 0}_{\mathbf{\delta}}$ & $\mathbf{p 1 1 0}$ \\
\hline $\mathbf{1 9}$ & 400 & 10000 & 2800 & 5100 & 37000 \\
\hline $\mathbf{2 0}$ & 34 & 3800 & 1700 & 2800 & 7900 \\
\hline
\end{tabular}

Table 6: Activity of DNA-PK inhibitors 19 and $20\left(\mathrm{IC}_{50} \mathrm{nM}\right)$ against various PI3Ks $[36,37]$.<smiles>O=Cc1ccc(N2CCOCC2)cc1O</smiles>

19: IC60211<smiles>O=c1cc(-c2ccccc2)oc2cc(N3CCOCC3)cc(O)c12</smiles>

20: IC87361
Scheme 6: Phenol related IC series.<smiles>CCc1[nH]c(/C=C2\C(=O)Nc3ccc(S(=O)(=O)Nc4ccccc4)cc32)c(CC)c1CCC(=O)O</smiles>

\section{1: SU11752}

Scheme 7: ATP-competitive DNA-PK inhibitor SU11752 (21)

tumours or lymphomas. Compound 22 has an $\mathrm{IC}_{50}$ of $88 \pm 64 \mathrm{nM}$ for inhibition of DNA-PKcs autophosphorylation (Ser2056) in A549 lung cancer cells, with good selectivity versus other PI3K family members [40] (Scheme 8). 
<smiles>[R20][R4]([R4])([R])[R4]</smiles>

Scheme 8: VX-984 (22).<smiles>COc1ccc([C@H](O)c2cc(-c3ncnc4cc(N5CCOCC5)ccc34)c(F)cc2Cl)nn1</smiles>

23: $\mathrm{M} 3814$

Scheme 9: M3814 (23)

\section{M3814}

Merck researchers have developed M3814 (23, also described as MSC2490484A), a highly potent and selective inhibitor of DNAPK [41]. In April 2017, information relating to the structure of the compound was released into the public domain [42]. M3814 entered phase I clinical development in December 2014 (NCT02316197) for use in patients with solid tumours who had DNA repair deficiencies, and in patients with Chronic Lymphocytic Leukaemia. M3814 later entered phase I trials in July 2015 (NCT02516813) in combination with DNA damaging modalities such as radio-chemotherapy and radiation. The ongoing trial incorporates a proof-of-principle study to examine the pharmacodynamic and mechanistic consequences of drug treatment. Disclosure of results by Merck in 2016, indicated that M3814 is active in a preclinical setting, exhibiting efficacy in all mouse models of human cancer, in combination with IR [41,43] (Scheme 9).

\section{Conclusion}

DNA-PK has all the potential hallmarks of an appealing and interesting therapeutic target, given its role in chemo- and radioresistance and implication in tumourigenesis, that the protein possesses a druggable kinase domain that is critical for DSB repair, that there are potential markers for assessing the pharmacodynamic activity of an inhibitor, and that additional markers of DSB repair are available to provide direct proof-of-mechanism. Previous investment made by academia and pharma alike, to identify inhibitors of DNA-PKcs activity has resulted in the identification of candidate drugs that are currently being tested clinically, as monotherapy and in combination with chemotherapy or radiotherapy. This progress may enable us to shortly realise the potential of exploiting DNA-PK inhibition for the benefit of cancer patients.

\section{Acknowledgements}

$\mathrm{SJH}, \mathrm{AB}$, and $\mathrm{CC}$ contributed equally to writing this review.

\section{References}

1. Smith GC, Jackson SP (1999) The DNA-dependent protein kinase. Genes \& development 13: 916-934.

2. Hill R, Lee PW (2012) The DNA-dependent protein kinase (DNA-PK): More than just a case of making ends meet? Cell Cycle 9: 3460-3469.

3. West SC (2003) Molecular views of recombination proteins and their control. Nature reviews Molecular cell biology 4: 435-445.

4. Jackson SP, Bartek J (2009) The DNA-damage response in human biology and disease. Nature 461: 1071-1078.

5. Khanna KK, Jackson SP (2001) DNA double-strand breaks: signaling, repair and the cancer connection. Nature genetics $27: 247-254$.

6. Collis SJ, DeWeese TL, Jeggo PA, Parker AR (2005) The life and death of DNA-PK. Oncogene 24: 949-961.

7. Hammarsten O, Chu G (1998) DNA-dependent protein kinase: DNA binding and activation in the absence of Ku. Proceedings of the National Academy of Sciences 95: 525-530.

8. West RB, Yaneva M, Lieber MR (1998) Productive and nonproductive complexes of $\mathrm{Ku}$ and DNA-dependent protein kinase at DNA termini. Molecular and cellular biology 18: 5908-5920.

9. Muller C, Christodoulopoulos G, Salles B, Panasci L (1998) DNA-dependent protein kinase activity correlates with clinical and in vitro sensitivity of chronic lymphocytic leukemia lymphocytes to nitrogen mustards. Blood 92: 2213-2219.

10. Willmore E, Elliott SL, Mainou-Fowler T, Summerfield GP, Jackson GH, et al (2008) DNA-dependent protein kinase is a therapeutic target and an indicator of poor prognosis in B-cell chronic lymphocytic leukemia. Clinical Cancer Research 14: 3984-3992

11. Li W, Xie C, Yang Z, Chen J, Lu NH (2013) Abnormal DNA-PKcs and Ku $70 / 80$ expression may promote malignant pathological processes in gastric carcinoma. World Journal of Gastroenterology: WJG. 19: 6894.

12. Abdel-Fatah TM, Arora A, Moseley P, Coveney C, Perry C, et al. (2014) ATM, ATR and DNA-PKcs expressions correlate to adverse clinical outcomes in epithelial ovarian cancers. BBA clinical 2: 10-17.

13. Cornell L, Munck JM, Alsinet C, Villanueva A, Ogle L, et al. (2015) DNA-PK - A Candidate Driver of Hepatocarcinogenesis and Tissue Biomarker That Predicts Response to Treatment and Survival. Clinical Cancer Research 21: 925-933.

14. Powis G, Bonjouklian R, Berggren MM, Gallegos A, Abraham R, et al. (1994) Wortmannin, a potent and selective inhibitor of phosphatidylinositol-3-kinase. Cancer research 54: 2419-2423.

15. Wymann MP, Bulgarelli-Leva G, Zvelebil MJ, Pirola L, Vanhaesebroeck B et al. (1996) Wortmannin inactivates phosphoinositide 3-kinase by covalent modification of Lys-802, a residue involved in the phosphate transfer reaction. Molecular and cellular biology 16: 1722-1733.

16. Walker EH, Pacold ME, Perisic O, Stephens L, Hawkins PT, et al. (2000) Structural determinants of phosphoinositide 3-kinase inhibition by wortmannin, LY294002, quercetin, myricetin, and staurosporine. Molecular cell 6: 909-919.

17. Izzard RA, Jackson SP, Smith GC (1999) Competitive and noncompetitive inhibition of the DNA-dependent protein kinase. Cancer Research 59: 25812586 .

18. Boulton S, Kyle S, Yalçintepe L, Durkacz BW (1996) Carcinogenesis 17: 2285 2290.

19. Vlahos CJ, Matter WF, Hui KY, Brown RF (1994) A specific inhibitor of phosphatidylinositol 3-kinase, 2-(4-morpholinyl)-8-phenyl-4H-1-benzopyran-4one (LY294002). Journal of Biological Chemistry. 269: 5241-5248.

20. Griffin RJ, Fontana G, Golding BT, Guiard S, Hardcastle IR, et al. (2005) Selective benzopyranone and pyrimido [2, 1-a] isoquinolin-4-one inhibitors of DNA-dependent protein kinase: Synthesis, structure- activity studies, and radiosensitization of a human tumor cell line in vitro. Journal of medicinal chemistry $48:$ 569-585. 
Citation: Harnor SJ, Brennan A, Cano C (2017) Inhibition of the DNA-Dependent Protein Kinase for Cancer Therapy. Med Chem (Los Angeles) 7: 172-177. doi: 10.4172/2161-0444.1000452

21. Hardcastle IR, Cockcroft X, Curtin NJ, El-Murr MD, Leahy JJ, et al. (2005) Discovery of potent chromen-4-one inhibitors of the DNA-dependent protein kinase (DNA-PK) using a small-molecule library approach. Journal of medicinal chemistry 48: 7829-7846

22. Cano C, Barbeau OR, Bailey C, Cockcroft XL, Curtin NJ, e al. (2010) DNAdependent protein kinase (DNA-PK) inhibitors. Synthesis and biological activity of quinolin-4-one and pyridopyrimidin-4-one surrogates for the chromen-4-one chemotype. Journal of medicinal chemistry 53: 8498-8507.

23. Veuger SJ, Curtin NJ, Richardson CJ, Smith GC, Durkacz BW (2003) Radiosensitization and DNA repair inhibition by the combined use of novel inhibitors of DNA-dependent protein kinase and poly (ADP-ribose) polymerase-1. Cancer research 63: 6008-6015.

24. Willmore E, de Caux S, Sunter NJ, Tilby MJ, Jackson GH, et al. (2004) A novel DNA-dependent protein kinase inhibitor, NU7026, potentiates the cytotoxicity of topoisomerase II poisons used in the treatment of leukemia. Blood 103: 46594665.

25. Hollick JJ, Rigoreau LJ, Cano-Soumillac C, Cockcroft X, Curtin NJ, et al. (2007) Pyranone, thiopyranone, and pyridone inhibitors of phosphatidylinositol 3-kinase related kinases. Structure- activity relationships for DNA-dependent protein kinase inhibition, and identification of the first potent and selective inhibitor of the ataxia telangiectasia mutated kinase. Journal of medicinal chemistry 50: 1958-1972.

26. Hollick JJ, Golding BT, Hardcastle IR, Martin N, Richardson C, et al. (2003) 2 , 6-disubstituted pyran-4-one and thiopyran-4-one inhibitors of DNA-Dependent protein kinase (DNA-PK). Bioorganic \& medicinal chemistry letters 13: 30833086.

27. Leahy JJ, Golding BT, Griffin RJ, Hardcastle IR, Richardson C, et al. (2004) Identification of a highly potent and selective DNA-dependent protein kinase (DNA-PK) inhibitor (NU7441) by screening of chromenone libraries. Bioorganic \& medicinal chemistry letters 14: 6083-6087.

28. Zhao Y, Thomas HD, Batey MA, Cowell IG, Richardson CJ, et al. (2006) Preclinical evaluation of a potent novel DNA-dependent protein kinase inhibitor NU7441. Cancer research 66: 5354-5362.

29. Clapham KM, Rennison T, Jones G, Craven F, Bardos J, et al. (2012) Potent enantioselective inhibition of DNA-dependent protein kinase (DNA-PK) by atropisomeric chromenone derivatives. Organic \& biomolecular chemistry 10 : 6747-6757.

30. Cano C, Saravanan K, Bailey C, Bardos J, Curtin NJ, et al. (2013) 1-Substituted (Dibenzo [b, d] thiophen-4-yl)-2-morpholino-4 H-chromen-4-ones Endowed with Dual DNA-PK/PI3-K Inhibitory Activity. Journal of medicinal chemistry 56: 6386-6401.

31. Munck JM, Batey MA, Zhao Y, Jenkins H, Richardson CJ et al. (2012)
Chemosensitization of cancer cells by KU-0060648, a dual inhibitor of DNA-PK and PI-3K. Molecular cancer therapeutics 11: 1789-1798.

32. Desage-El Murr M, Cano C, Golding BT, Hardcastle IR, Hummersome M et al (2008) 8-Biarylchromen-4-one inhibitors of the DNA-dependent protein kinase (DNA-PK). Bioorganic \& medicinal chemistry letters 18: 4885-4890.

33. Clapham KM, Bardos J, Finlay MR, Golding BT, Griffen EJ, et al. (2011) DNAdependent protein kinase (DNA-PK) inhibitors: structure-activity relationships for O-alkoxyphenylchromen-4-one probes of the ATP-binding domain. Bioorganic \& medicinal chemistry letters 21: 966-970.

34. Cano C, Golding BT, Haggerty K, Hardcastle IR, Peacock M, et al. (2010) Atropisomeric 8-arylchromen-4-ones exhibit enantioselective inhibition of the DNA-dependent protein kinase (DNA-PK). Organic \& biomolecular chemistry 8: 1922-1928.

35. Mould E, Berry P, Jamieson D, Hill C, Cano C, et al. (2014) Identification of dual DNA-PK MDR1 inhibitors for the potentiation of cytotoxic drug activity. Biochemical pharmacology 88: 58-65.

36. Knight ZA, Chiang GG, Alaimo PJ, Kenski DM, Ho CB, et al. (2004) Isoformspecific phosphoinositide 3-kinase inhibitors from an arylmorpholine scaffold. Bioorganic \& medicinal chemistry 12: 4749-4759.

37. Kashishian A, Douangpanya H, Clark D, Schlachter ST, Eary CT, et al. (2003) DNA-dependent protein kinase inhibitors as drug candidates for the treatment of cancer. Molecular cancer therapeutics 2: 1257-1264.

38. Shinohara ET, Geng L, Tan J, Chen H, Shir Y, et al. (2005) DNA-Dependent Protein Kinase Is a Molecular Target for the Development of Noncytotoxic Radiation-Sensitizing Drugs. Cancer research. 65: 4987-4992.

39. Ismail IH, Mårtensson S, Moshinsky D, Rice A, Tang C, et al. (2004) SU11752 inhibits the DNA-dependent protein kinase and DNA double-strand break repair resulting in ionizing radiation sensitization. Oncogene 23: 873-882.

40. Boucher D, Hoover R, Wang Y, Gu Y, Newsome D, et al. Potent radiation enhancement with VX-984, a selective DNA-PKcs inhibitor for the treatment of NSCLC.

41. Zenke FT, Zimmermann A, Sirrenberg C, Dahmen H, Vassilev L, et al. (2016) M3814, a novel investigational DNA-PK inhibitor: enhancing the effect of fractionated radiotherapy leading to complete regression of tumors in mice.

42. Fuchss T, Mederski WWKR, Emde U, Buchstallter HP, Zenke F, et al. (2014) Highly potent and selective DNA-PK inhibitor M3814 with sustainable antitumor activity in combination with radiotherapy. Proc Amer Assoc Cancer Res, p: 4198.

43. Damstrup L, Zimmerman A, Sirrenberg C, Zenke F, Vassilev L (2016) M3814, a DNA-dependent Protein Kinase Inhibitor (DNA-PKi), Potentiates the Effect of lonizing Radiation (IR) in Xenotransplanted Tumors in Nude Mice. Internationa Journal of Radiation Oncology Biology Physics 94: 940-941. 